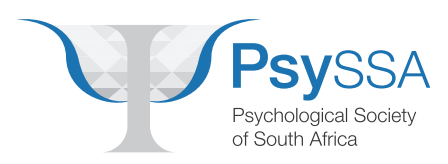

\title{
Decoloniality and psychology's reckoning with rebellion
}

\section{Shahnaaz Suffla ${ }^{1,2}$ iD and Mohamed Seedat ${ }^{1,2}$}

When we revolt it's not for a particular culture. We revolt simply because, for many reasons, we can no longer breathe.

The recent acts of anti-Black racism, in both their extraordinary and everyday manifestations of the disposability of Black life, have (re)produced analyses of the social anatomy of systemic racism, and ignited old and new rebellions against racial oppression and White supremacy across the world. These insurgences for the being of Black life - in embodiment, affect, cognition, spirituality and materiality - represent yet another seminal contemporary moment in the prefigurative politics of liberation and, concomitantly, the psychopolitics of liberation. Psychology's epistemologies, intent, occupations and social actors are beckoned once more then, through the urgencies of the current interlocking crises, to confront matters of complicity and silence, as well as to (re)commit to the imaginations, values, consciousness and actions that espouse insurrectionist agendas for change, healing, care, relationality, community, mutuality and solidarity. Critical herein is recognition of the indivisibility of colonial, historical, spatialised and embodied wounds and suffering, and equally the indivisibility of the requisite justices and emancipatory labour to account for the full humanity (see Maldonado-Torres, 2016) of all oppressed people.

The philosophical and political questions that prod - indeed, continue to prod - at psychology's constitutive formations raise deeply fundamental questions about psychology's ultimate will to serve the wretched of the earth. Frantz Fanon's (1963/2004) decolonial call more than 50 years ago for radical sociogeny, or what Bulhan (1985) in his work on the psychology of the oppressed translates as a psychology embedded in a social dialectic that gives way to new conceptions of humanity, remains a largely unfulfilled project of emancipation in the discipline as we know it. Yet, the entreaty for a profound reimagining and praxis of being human - in Sylvia Wynter's (2003) thesis, the pursuit of a revisioned humanism - lies at the very core of psychology's identity and enterprise, let alone liberatory imperatives (see Seedat, 1997), or at least should. In this, of course, are enclosed

\footnotetext{
'Institute for Social and Health Sciences, University of South Africa, South Africa

${ }^{2}$ Masculinity and Health Research Unit, South African Medical Research Council, University of South Africa, South Africa 
axiomatic questions of what it means to be Black in the world (see Biko, 2004; Manganyi, 1973) and, by implication, the principles, forms and collectiveness of our rebellions to the violences of White consciousness, White privilege and racial capitalism on Black lives.

As Black psychologists, and Black citizens, our own immersions and entanglements in psychology are hardly without ambivalence and tension. After all, attempts over the last four decades to transform psychology's onto-epistemological treatment of the Other have largely failed. We wrestle with our expectations of what has not only derived, but also flourished, as essentially a racist colonial entity (psychology's collusion with the colonial apartheid system is by now well established - see Suffla et al., 2001) that continues to struggle to liberate itself from its limited and limiting notions of change, justice and healing. Together with other collectives of resistance in Africa and beyond, we coax the demise of anti-Black racist psychologies as we agitate, with and against their primacy, to rethink and reinscribe the frames of disciplinary knowledge, and philosophies of reason and service that are equally and justly humanising of the Black Other. Here, we find appositely instigating the pronouncement by Ratele and his colleagues (2020) that if embracing the way that psychology bends and contorts under the emancipatory requirements of feminism, decoloniality and Africa(n)-centredness gives rise to something that looks very little like psychology as we know it, then so be it' (p. 14).

In this timbre, we turn to Fanon's (1965) notion of radical mutations to argue for forms of transfigurations within psychology that can no longer be self-indulgent. To challenge the logics of colonialism, Fanon's (1965) visions for building a new society and new humanity called for radical mutations in social structures, relations and consciousness. For Fanon (1965), such mutations, or change in struggle, represent 'a radical change of valence, not a back-and-forth movement but a dialectical progression' (p. 90), that implicates internal-external conditions for desired transformation. From this perspective, and at present in challenge of the logics of coloniality (see MaldonadoTorres, 2016), the fostering of anti-racist psychologies for anti-racist action compels deep undoings and redoings within and without the prevailing borders of the discipline. As strivings towards radical mutation, these (un)(re)doings imply ideological, epistemological, ontological, methodological, praxical, pedagogical and organisational provisions for change. Certainly, the conditions for transformation are many and portend upheaval. Certainly, this speaks to psychology's own reckoning with rebellion.

The critical disruptions to which we point emanate undoubtedly from our own decolonial orientation. Yet, the politicisation of the discipline, in our view, cannot remain any longer the concern, commission or domain of some and not all. To underline, at this juncture, the will and work of psychology(ies) must necessarily be bound to philosophies and praxes of liberation (see Dussel, 1985; Freire, 1970; Martín-Baró, 1994) that render legible and visible resistances to anti-Black racism, and equally to all other forms of oppression. The compass and centrum of such a liberatory framework implicate - at the very least - the imbricated imperatives of critique, commitment and critical engagement.

Critique is self-evidently essential to move beyond the reductions, redactions and totalisations imposed by the White, masculinist, heteronormative, Eurocentric gaze and episteme in which psychology is cast. Imagining and inventing possibilities for radical mutation requires discerning and disclaiming the persisting forces that reproduce psychology's problematics and forms, including the systemic and institutional arrangements by which they are buttressed, as well as the regressive currents and voices that invoke the rhetorics of democracy to subvert change and maintain inertia. In turn, the commitment that is petitioned through a liberatory framework is of the constitution that turns away from the discipline's narrow preoccupation with itself, held in place by a disproportionate focus on such factors as guild interests, professional status and disciplinary privilege, towards forms of psychopolitical consciousness that recognise and honour the full humanity of the Other. 
Here, the psychopolitical potency of rebellion and mutation not only reinforces the personal-political dialectic, but also inevitably demands that we rethink psychology's cardinal terms of reference if the discipline is to be meaningfully responsive to the major challenges and priorities of our time, including anti-Black racism and anti-racist action. The psychopolitics of liberation signify, of course, critical engagement towards forging new and alternative ways of thinking and doing. Critical engagement, through reimaginings, ruptures and recuperations, and in conscious activism, struggle and solidarity against anti-Black racism and the demunanisation of the Other, brings us closer to the kinds of freedoms and justices to which psychology must surely commit. Engaging possibilities for radical mutations in our thinking and doing - for new forms of psychologies - is to work towards the praxis of radical humanism, so profoundly conveyed by Fanon's (1967/2008) invocation, 'I want the world to recognize, with me, the open door of every consciousness' (p. 181).

Thinking and writing on the quest for liberatory psychology - in solidarity with other radical Black psychologists - Seedat reflected as far back as 1997 on psychology's obedience to the philosophical and political mission of coloniality. In 2020, surely rebellion needs no more reason. Surely, the right to breathe belongs to all.

\section{Declaration of conflicting interests}

The author(s) declared no potential conflicts of interest with respect to the research, authorship, and/or publication of this article.

\section{Funding}

The author(s) received no financial support for the research, authorship and/or publication of this article.

\section{ORCID iD}

Shahnaaz Suffla iD https://orcid.org/0000-0002-4597-5472

\section{References}

Biko, S. (2004). I write what I like. Picador Africa.

Bulhan, H. A. (1985). Frantz Fanon and the psychology of oppression. Plenum Press.

Dussel, E. (1985). Philosophy of liberation. Orbis Books.

Fanon, F. (2004). The wretched of the earth. Grove Press. (Original work published 1963)

Fanon, F. (1965). A dying colonialism. Grove Press.

Fanon, F. (2008). Black skin, white masks. Grove Press. (Original work published 1967)

Freire, P. (1970). Pedagogy of the oppressed. Herder and Herder.

Maldonado-Torres, N. (2016). Outline of ten theses on coloniality and decoloniality. http://fondation-frantzfanon.com/outline-of-ten-theses-on-coloniality-and-decoloniality/

Manganyi, N. C. (1973). Being-black-in-the-world. Ravan Press.

Martín-Baró, I. (1994). Writings for a liberation psychology. Harvard University Press.

Ratele, K., Malherbe, N., Cornell, S., Day, S., Helman, R., Makama, R., . . Dlamini, S. (2020). Elaborations on (a) decolonising Africa(n)-centred feminist psychology. Psychology in Society, 59, 1-19.

Seedat, M. (1997). The quest for liberatory psychology. South African Journal of Psychology, 27(4), 261-270.

Suffla, S., Stevens, G., \& Seedat, M. (2001). Mirror reflections: The evolution of organized professional psychology in South Africa. In N. Duncan, A. van Niekerk, C. de la Rey, \& M. Seedat (Eds.), Race, racism, knowledge production and psychology in South Africa (pp. 27-36). Nova Science Publishers.

Wynter, S. (2003). Unsettling the coloniality of being/power/truth/freedom: Towards the human, after man, its overrepresentation - An argument. CR: The New Centennial Review, 3(3), 257-337. 